\title{
South Africa's move away from international investor-state dispute: a breakthrough or bad omen for investment in the developing world?
}

\author{
Mmiselo Freedom Qumba \\ $L L M$ \\ Lecturer, Mercantile Law Department, University of the Free State
}

\begin{abstract}
SUMMARY
In late 2015, the South African government terminated all bilateral investment treaties it had signed with European countries and promulgated the Protection of Investment Act. Among the changes to the country's foreign investment regime introduced by the new Act is the removal of international investment arbitration at the International Centre for the Settlement of Investment Disputes (ICSID). An overview of recent developing-world trends points to an eagerness to facilitate a better balance between foreign investors' interests and those of the host state. In most instances, this is done by introducing domestic courts and tribunals as both first and last resort for foreign investment disputes. Against this backdrop, South Africa's move away from investor-state dispute settlement was not completely unexpected. Questions can however be raised as to whether this is an outright rejection of investor-state dispute settlement, without first establishing some sort of alternative capacity-wise. The article concludes that, in resource-constrained times, it might have been more prudent to safeguard valuable inflows of investment and resist scrapping investor-state dispute settlement in its entirety, at least until workable alternatives - such as the creation of a regional, custom-made investment arbitration system - have been secured.
\end{abstract}

\section{Introduction}

A provision relating to the settlement of investment disputes constitutes a key component of any bilateral investment treaty (BIT) between a host nation and foreign investor, ${ }^{1}$ guaranteeing the investor access to a neutral forum for the resolution of any potential investment disputes with the host state. ${ }^{2}$ The creation of the International Centre for the Settlement of Investment Disputes (ICSID) in 1966 provided such an independent dispute settlement forum, and offered foreign investors a guarantee that their investments would not be subjected to the political pressures of adjudication in host nations' national courts. ${ }^{3}$

Sornarajah The International Law on Foreign Investment (2010) 216.

Sornarajah 217.

Gas Natural SA $v$ The Argentine Republic ICSID Case No ARB/03/10 para 29.

How to cite: Qumba 'South Africa's move away from international investor-state dispute: a breakthrough or bad omen for investment in the developing world?' 2019 De Jure Law Journal 358-379 http://dx.doi.org/10.17159/2225-7160/2019/v52a19 
Established by the multilateral Convention on the Settlement of Investment Disputes between States and Nationals of Other States (or the "ICSID Convention"), the ICSID has been widely accepted as the world's leading depoliticised institution devoted to international investment dispute resolution. As such, states worldwide have agreed to abide by its jurisdiction in their international investment treaties, investment laws and contracts, ${ }^{4}$ - even countries such as South Africa, which was not a party to the ICSID Convention. ${ }^{5}$ With the boom in BITs in the 2000s, it seemed settled that the ICSID would only grow in membership and reach. ${ }^{6}$

Things have however taken a surprising turn. In the past few years, some states have expressed dissatisfaction with the way in which the ICSID settles disputes, and have consequently taken a step back from international arbitration. This has seen nations such as Ecuador, Australia, Venezuela and Indonesia withdrawing from the provisions on investor-state dispute settlement in their BITs. ${ }^{7}$ Equally unhappy with the rulings of the ICSID, the South African government too resolved to move away from international investment arbitration. Therefore, the central factor in government's decision to terminate its BITs was the matter of Piero Foresti, Laura de Carli $v$ Republic of South Africa. ${ }^{8}$ The case was the first time that the South African government had been put under the test about its policies and how they relate to investment.

Importantly, the Foresti case was the second case against the South African government under the international investment law. The first had been one raised by a Swiss citizen claim that South Africa had failed to provide protection and security under the Swiss-RSA BIT. This international arbitration case against South Africa was initiated in 2003 under the Swiss-South Africa investment treaty. The case involved a private game lodge and farm in the North-eastern part of South Africa that a Swiss investor acquired during apartheid years, and substantially improved. In this case, the foreign investor's property was vandalised by protests and destroyed by South African nationals. Consequently, the Swiss investor took the South African government to international Arbitration. Claimants alleged that South Africa had violated the Full Protection and Security. The South African government was found to

4 International Center for Settlement of Investment Disputes World Bank Group available at https://icsid.worldbank.org/en/Pages/process/Other-ADRMechanisms.aspx (accessed 2018-01-22).

5 Piero Foresti, Laura de Carli $v$ Republic of South Africa ICSID Case No $\mathrm{ARB}(\mathrm{AF}) / 07 / 1$

6 Schlemmer "An overview of South Africa's bilateral investment treaties and investment policies” 2016ICSID Review - Foreign Investment Law Journal 167.

7 Olivet "Why did Ecuador leaves its bilateral Investment Treatie?" available at https://www.tni.org/en/article/why-did-ecuador-terminate-all-its-bilateralinvestment-treaties ( accessed 2019-01-22).

8 Piero Foresti, Laura de Carli v Republic of South Africa supra. 
have breached its obligation to protect and secure the Swiss investor, and an award was rendered against South Africa. ${ }^{9}$

Therefore, government's decision to review its policy was triggered by the 2010 Foresti case and Swiss-Investor, in which South Africa was sued by a group of Italian investors who were challenging the country's black economic empowerment legislation. Having terminated some of its existing BITs, the country promulgated the new Protection of Investment Act 22 of $2015 .^{10}$ In their assessment of their risk and benefits associated with BITs, the government found that the international investment regime mainly focused on narrow issues of economic interests, while matters of national interests were exposed to unpredictable system of international arbitration, which undermined the constitutionality of the state and its space to determine domestic policy. The government noted that the proponents tended to argue BITs encourage investment and strengthen the rule of law particularly in jurisdictions where the court systems are weak or biased against a foreigner. In the government's perspective, such position is contested. It also argued that there is no correlation between FDI inflows and signing of the BITs. The Protection of investment Act came into effect under the guidance of President Cyril Ramaphosa in July 2018. Amongst others, the Protection of Investment Act provides for a mediation and arbitration process that is to be facilitated by the South African Department of Trade and Industry, and expresses a clear preference for domestic courts as a forum for resolving investor-state disputes. ${ }^{11}$

This decision by the South African government to move away from the established investor-state dispute settlement system in the form of the ICSID has come under fierce criticism, ${ }^{12}$ and raises a number of critical questions about the direction in which government has opted to steer its foreign investment law. Firstly, it raises questions about foreign investors' confidence in the settlement of investment disputes through the as-yet untested means of mediation and arbitration facilitated by the Department of Trade and Industry. Secondly, the South African courts' suitability for the settlement of investment disputes is called into question, with concerns expressed that the courts may struggle to uphold foreign investors' private property rights in the face of the social and public-interest realities of South Africa. Finally, questions are being asked about whether South Africa's departure from the ICSID should be regarded as a pioneering move that may help set new standards for

9 Schlemmer 2016ICSID Review - Foreign Investment Law Journal 168.

10 The government terminated BITs with the following countries the UK, the Netherlands, Switzerland, Germany, France, Cuba, Denmark, Australia, Italy, Sweden, Argentina, Finland, Spain \& Greece, as well as BelgiumLuxembourg Economic Union.

11 The Protection of Investment Act 22 of 2015.

12 Gazzini "Rethinking the Promotion and Protection of Investment: The 2015 South Africa's Investment Act" available at https://dx.doi.org/10.2139/ ssrn.2960567 (accessed 2018-01-22). 
developing countries' approach to foreign investors and investment arbitration.

This contribution aims to assess whether the investor-state dispute settlement system of the ICSID is a system worth preserving, or whether opting for local mediation procedures, exhaustion of local remedies before resorting to ICSID, revitalising the SADC Tribunal, dispute settlement in domestic courts, may be a better alternative, particularly for emerging economies in the African continent. Since ICSID arbitration still accounts for most of the treaty arbitrations when compared to nonICSID arbitration such as UNCITRAL arbitration, this paper focuses mainly on the design of the ICSID arbitration. Much of non-ICISD treaty arbitration resembles the approach taken in the ICISD convention. To this end, arguments for and against the investor-state dispute settlement system are first discussed, and potential solutions to the challenges of the system cited. The provisions of investor-state dispute settlement under the previous South African BIT regime are then compared with the dispute resolution method under the new investment regulation regime to assess whether other developing countries should follow South Africa's deliberate break with investor-state dispute settlement at the ICSID.

\section{Arguments for and against the investor-state dispute settlement system}

\section{Strength: protecting investor and host state alike}

In constructing the ICSID, its architects stressed in the preamble to the ICSID Convention "the need for international cooperation for economic development, and the role of private international investment therein". In an early edition of the published Convention, Aron Broches, then general counsel of the World Bank, explained the motivation behind the establishment of the ICSID as the fear of political risks and biasness associated with national courts. Thus, investor-state dispute settlement is aimed at protecting both the investor and the host state, to the same extent and with the same vigour, not forgetting that to protect investment entails protecting the general interest of development, including the interests of developing countries. ${ }^{13}$ The World Bank executive directors in their 1965 report on the ICSID Convention echoed this as an institution designed to facilitate investment disputes between foreign investors and host states thereby creating mutual confidence and promoting investment inflows to host states. ${ }^{14}$

13 Gas Natural SA $v$ The Republic of Argentina supra, para 29.

14 World Bank Group, CSID Convention, Regulations and Rules 2006 available at https://Icsid.worldbank.org/cn/Documents/icsid.docs/ICSID \% 20Con vention \% 20English.pdf (accessed 201 8-01-22). 


\section{Strength: direct recourse to an international forum}

Apart from providing equal protection, investor-state dispute settlement instruments also affords foreign investors the right to initiate arbitration proceedings directly against the host state at an independent international forum. ${ }^{15}$ The value of such a mechanism was confirmed in the matter of Gas Natural SA $v$ The Argentine Republic, ${ }^{16}$ In that case, the tribunal identified the avoidance of the political pressures and delays inherently associated with adjudication in national courts as the primary reason for the creation of the ICSID and the subsequent adoption of a wave of BITs. This direct recourse to an international forum against the host state is therefore seen to reduce the political risks associated with investments. 17

\section{Strength: ensuring stable and predictable international investment relations}

Proponents of investor-state dispute settlement regard it as a legitimate mechanism for structuring and stabilising international investment relations, without institutionalising a pro-investor bias and disregarding the host state's power to regulate. ${ }^{9}$ Arbitrators, they argue, strive to be fair and impartial in their decisions, as they set a high value on their professional reputation. ${ }^{19}$ To support this claim, staunch supporters of investor-state dispute settlement implore critics to examine the outcomes of arbitral awards, which are believed to illustrate the legitimacy of the system and the independence and impartiality of the arbitrators. $^{20}$ In addition, by holding the host state to the terms and obligations of the investment instruments, investor-state dispute settlement ensures certainty and predictability for investors, seeing to it that the host state's contractual promises are kept. ${ }^{21}$

15 United Nations Conference on Trade and Development "The Role of International Investment Agreements in Attracting Foreign Direct Investment to Developing Countries" available at https://unctad.org/en/ Docs/diaeia20095-en.Pdf (accessed 2018-01-23).

16 Gas Natural SA $v$ The Argentine Republic supra, 29.

17 Schill "In Defence of International Investment Law" 2016 European Yearbook of International Economic Law 314.

18 Brower \& Schill "Is arbitration a threat or a boon to the legitimacy of international investment law?" 2009 Chicago Journal of International Law 472.

19 Kapeliuk "The repeat appointment factor: Exploring decisions patterns of elite investment arbitrators" 201096 Cornell Law Review 89.

20 Blythe "The Advantages of Investor-State Arbitration as a Dispute Resolution Mechanism in Bilateral Investment Treaties" 2013 International Investment Law Journal 273.

21 Blythe 2013 International Investment Law Journal 273. 


\section{Strength: pro-host rather than pro-investor}

The matter of Chemtura Corporation $v$ Canada, ${ }^{22}$ is often cited to counter arguments that investor-state dispute settlement has little compassion for host governments. In this matter, Chemtura, a United States agricultural product company (investor), alleged that its partner in Canada (host) wrongfully terminated its pesticides business. Chemtura alleged violations of the minimum standards of treatment as well as wrongful expropriation. The tribunal dismissed all claims, finding that the measures had not amounted to substantial deprivation of the claimant's investment and were in fact taken legitimately and without bad faith. Moreover, the European Federation for Investment Law and Arbitration (EFILA) points out that according to the United Nations Conference on Trade and Development, at least $53 \%$ of cases decided by the ICSID are in favour of host states. EFILA then goes on to give compelling reasons that suggest that investor-state dispute settlement is in fact pro-jurisdiction rather than pro-investor. ${ }^{23}$

\section{Strength: swift, final and enforceable decisions to protect against expropriation}

Investor-state dispute settlement enables foreign investors to hold host states accountable for unreasonable interferences with their investments. ${ }^{24}$ In particular, it offers a mechanism for rendering swift, enforceable and depoliticised awards in the event of indirect and direct expropriation without compensation, ${ }^{25}$ - a matter in which host-state courts' neutrality is generally called into question, ${ }^{26}$ irrespective of the sophistication of their legal systems.

While problems with non-compensated expropriation are often encountered in jurisdictions with underdeveloped legal systems, posing threats of lengthy court proceedings and corruption, ${ }^{27}$ South Africa, with its advanced judiciary and legislative framework, has certainly not proven itself beyond reproach in this regard. In 2009, for instance, the Constitutional Court established physical acquisition of property by the state as a prerequisite for expropriation to be recognised in South African law. $^{28}$ This differs from the position in international law, which

22 Chemtura Corporation v Canada UNCITRAL 2 Aug 2010.

23 Alverez "Response to the Criticism against ISDS by EFILA" Journal of international arbitration

24 Schill 2016 European Yearbook of International Economic Law 315.

25 United Nations Conference on Trade and Development Reform of investorstate dispute In search of a roadmap available at https://unctad.org/en/ publicationsLibrary/webdiaeapcb2013d4-en.pdf (accessed 2018-1-24).

26 United Nations Conference on Trade and Development "Reform of investorstate dispute In search of a roadmap" supra.

27 United Nations Conference on Trade and Development "Reform of investorstate dispute In search of a roadmap" supra.

28 In Reflect-All 1025 CC v MEC for Public Transport, Roads and Works, Gauteng Provincial Government 2009 4 SA CAC 15. 
recognises indirect expropriation without physical acquisition. ${ }^{29}$ In addition, the South African Constitution, together with jurisprudence that has emerged from the Constitutional Court, fails to distinguish between direct and indirect expropriation, but prefers the words "deprivation" and "expropriation". In 2013, the Constitutional Court went on to define deprivation of private property rights as "sacrifices that holders of private property rights may have to make without compensation". 30

As the law relating to expropriation continues to evolve in South Africa, ${ }^{31}$ particularly so with Parliament's stated intention of amending section 25 of the Constitution to expropriate land without compensation, the attraction of investor-state dispute settlement from a foreign investor's perspective is easy to comprehend.

\section{Strength: striking a balance between investors' and public interest}

Although the South African courts are impartial and independent, the role of the South African judiciary still is to be loyal to local public interests such as affirmative action and black economic empowerment (BEE) policies, which have been entrenched in the legal system by way of various national laws. ${ }^{32}$ Therefore, while these policies are often viewed as detrimental to foreign investors, the South African courts are bound by the Constitution to give effect to their provisions to transform society.

This was confirmed in the matter of Agri SA $v$ Minister of Mining and Energy, ${ }^{33}$ where the court acknowledged the social context of South Africa and decided, "not to over-emphasise private property rights at the expense of the state's social responsibilities". 34 Another good illustration of the conflict between the protection of foreign investors and the public interest is found in the case of Piero Foresti, Laura de Carli $v$ Republic of South Africa, ${ }^{35}$ which also served as one of the key triggers for South Africa's decision to terminate its BITs. The claimants in the matter argued that by requiring mining companies to transfer $26 \%$ ownership of mining assets to historically disadvantage South Africans, the Mining Charter advocated indirect expropriation and also breached the obligation of fair and equitable treatment, which prohibits

29 United Nations Conference on Trade and Development "Expropriation" available at https://unctad.org/en/Docs/unctaddiaeia2011 d7_en.pdf (accessed 2018-01-22)

30 Agri SA $v$ Minister of Mining and Energy 20134 SA (CC) 1

31 Klaaren \& Schneiderman "SA Bilateral Investment Treaty Policy Framework Review" available athttp://wiredspace.wits.ac.za/bitstream/handle/105/39/ 9205/SABITpolicyreviewcommentsKlaaren (accessed 2018-01-24).

32 Qumba "Safeguarding foreign direct investment in South Africa: Does the Protection of investment Act live up to its name?" 2018 South African Journal of International Affairs 354.

33 Agri SA $v$ Minister of Mining and Energy supra.

34 Agri SA $v$ Minister of Mining and Energy supra.

35 Piero Foresti, Laura de Carli v Republic of South Africa supra. 
discrimination. ${ }^{36}$ They further claimed that the BEE equity divestiture requirement that required foreign investors to sell $26 \%$ of their shares to historically disadvantaged South African companies amounted to expropriation. In response, the South African government argued that even if one was to admit that the Mining Charter treated foreign investors differently from their South African counterparts, the differentiated treatment would be legitimate, ${ }^{37}$ falling squarely within government's margin of appreciation for determining which measures were reasonable and justifiable in advancing critical public interests. Thus, government contended that there could not have been indirect expropriation when, as in this case, government's actions were a rational and a proportional means of pursuing legitimate public regulatory purposes. The parties eventually reached a settlement, and the case was never argued on merit.

In short, therefore, both Agric and Foresti illustrate that foreign investors may indeed suffer the consequences of measures aimed at redressing past racial discrimination, realising land reform and promoting equitable access to South Africa's natural resources. While certainly legitimate from a social and political point of view, these measures raise concerns among foreign investors that their private property rights and business interests will be rendered worthless when pitted against the country's social transformation imperative. This, investor-state dispute settlement has been rather effective in hedging against.

\section{Weakness: seen as pro-investor and anti-host, and thus no guarantee of economic growth}

The ICSID dispute resolution system has been attacked for being biased towards investors and against host state governments, with nontransparent and inconsistent awards ${ }^{38}$ allegedly heavily influenced by private firms and multinational corporations. ${ }^{39}$ Concerning the inconsistency of the awards, the following Argentinian cases interpreting Full Protection and Security standard of BITs, are instructive. The administrative tribunal have held that is inappropriate to depart from the originally understood standard of "protection and constant security", 40 while on the other hand it has been found that the phrase "protection and constant security" 41 as related to the subject matter of treaty does not carry with it an implication that this protection is inherently limited to protection and security of physical assets. A prime example of a case where the ICSID tribunal has ordered outrageous cost

36 Piero Foresti, Laura de Carli v Republic of South Africa supra.

37 Piero Foresti, Laura de Carli v Republic of South Africa supra.

38 Forere "Move away from BITs framework" supra, par 9.

39 Gazzini "Rethinking the Promotion and Protection of Investment: The 2015 South Africa's Investment Act" available at https://dx.doi.org/10.2139/ ssrn.2960567 (accessed 2018-01-22).

40 BG Group Plc. $v$ The Republic of Argentina UNCITRAL.

41 National Grid plc $v$ The Argentine Republic UNCITRAL. 
order is the case of Occidental Petroleum Corp and Occidental Exploration Production Company V Republic of Ecuador, ${ }^{42}$ On 5 October 2012, an investment arbitration tribunal ordered the government of Ecuador to pay 2, 3 billion USD to the United States oil company occidental. It was the largest amount a state had been ordered a State been ordered to pay by an investor-state tribunal up to that point. For Ecuador that sum represented $59 \%$ of the country's 2012 Annual budget for education and $135 \%$ of the country's annual health care budget. Following suit, the President Rafael Correa of Ecuador publicly announced that he "had no confidence in the World Bank arbitration branch (ICSID) that heard the US oil company occidental law suit against Ecuador" and explained that "Ecuador handed over its sovereignty" when it signed international accords binding it to the Bank's ICSID. 43

Indeed, some due-diligence findings have pointed to business connections between certain international investment arbitrators and foreign investors. What also transpired from due-diligence tests was that international investment arbitration was no longer cost-effective because of inordinate delays. ${ }^{44}$ This is said to expose host states to protracted legal battles and arbitral claims that may trigger large sums of compensation. In the case of Amco Asia Corporation and others $v$ Republic of Indonesia, ${ }^{45}$ Indonesia requested the disqualification of Edward W. Rubin, the Claimant-appointed arbitrator in the case. Prior to his appointment as an arbitrator (but after the initiation of arbitration proceedings), Rubin had given tax advice to the controlling shareholder of the corporate Claimant. Furthermore, his law firm had shared office space and administrative services with counsel for Claimant for about half a year into the arbitration proceedings. A long-standing profitsharing arrangement between the firms had been discontinued before the arbitration was initiated. Indonesia argued that these circumstances affected the arbitrator's independence. Also in Compañia de Aguas del Aconquija S.A. and Vivendi Universal S.A. $v$ Argentine Republic. ${ }^{46}$ Argentina challenged the president of the ad hoc Annulment Committee, Yves Fortier Q.C. One of the partners at his law firm had previously provided tax advice to the corporate predecessor of one of the Claimants (Vivendi Universal S.A.). Fortier was not personally involved in the tax advice, which was furthermore unrelated to the claim against Argentina.

Put differently, it is claimed that the investor-state dispute settlement system has enabled narrow commercial interests to subject matters of

42 Occidental Petroleum Corp and Occidental Exploration Production company $v$ Republic of Ecuador ICSID NO ARB/06/11.

43 Vincetelli "The uncertain future of ICSID in Latin America" 2010 Law and Business Review 409.

44 Mossalam 'The Process matters: South African Experience in exiting it BITs" supra.

45 Amco Asia Corporation and others $v$ Republic of Indonesia (Amco Asia), ICSID Case No ARB/81/1.

46 Compañia de Aguas del Aconquija S.A. and Vivendi Universal S.A. v Argentine Republic ICSID Case No ARB/97/3. 
vital national interest to unpredictable international arbitration, which in many instances has frustrated legitimate, constitutional and democratic policymaking. As such, the effectiveness of the BITs to guarantee protection of investors as a driving force for economic development has come under scrutiny, ${ }^{47}$

with claims of a lack of conclusive evidence that such BITs are indeed necessary to attract foreign investment and boost economic growth. ${ }^{48}$

\section{Weakness: incapable of addressing domestic policy issues}

By allowing foreign investors to bypass the host's national courts and take investment disputes directly to an international investment tribunal, the host nation's government policies are subjected to scrutiny by a third party, which undermines its sovereignty and regulatory power. ${ }^{49}$ From a South African perspective, it is argued that the international arbitration system is not equipped to deal with domestic policy issues, and that its arbitrators are therefore likely to render decisions that would upset the delicate balance that the country's new Protection of Investment Act seeks to achieve. ${ }^{50}$ Meanwhile, the country boasts an impartial and robust judiciary guaranteed by the Constitution, ${ }^{51}$ which to government's mind is sufficiently equipped to resolve foreign investment disputes with due regard of all parties' interests.

\section{High costs of proceedings}

The ICSID arbitration system has been attacked for being skewed against host governments and in favour of foreign investors in its awards. As a result, many a host nation has called into question the legitimacy of international investor-state arbitration and its ability to balance the interests of both foreign investors and host states. ${ }^{52}$ This perceived favouring of foreign investors also extends to the costs associated with the arbitration and the astronomical sums of compensation that host nations are often expected to pay. In 2012, for instance, an investor from the United States was awarded close to US\$1, 9 billion for a claim against the government of Ecuador. ${ }^{53}$ Low-income countries from Africa and elsewhere often lack the resources to defend themselves against

47 Department of trade and Industry "Bilateral Investment Treaty Policy Framework Review" supra.

48 Sornarajah 216.

49 Mossalam "The Process matters: South African Experience in exiting it BITs" supra.

50 Subedi International Investment Law: Reconciling Policy and Principle (2008) 354.

51 Subedi 354

52 Sornarajah 190.

53 Occidental Petroleum Corporation and Occidental Exploration and Production Company $v$ The Republic of Ecuador ICSID case no ARB/06/11. 
multinational corporations. ${ }^{54}$ The fees charged by investment lawyers are not always known or disclosed, while participation by public-interest groups are often inhibited due to the high cost of travelling to arbitration venues in global cities such as New York, Paris and London. ${ }^{55}$

\section{Lack of diversity of arbitrators}

Concerns have been raised over the lack of diversity in the appointment of arbitrators, and particularly the lack of Africans serving on the ICSID and other international tribunals. ${ }^{56}$ Critics argue that, since there are many excellent African scholars playing key roles elsewhere in the international domain, the lack of African arbitrators in the ISDS system can only point to a deliberate attempt to avoid diversity. ${ }^{57}$ Admittedly, the lack of African representation at the ICSID is not ideal for the purposes of developing African-based jurisprudence in ICSD arbitration. The lack of African jurisprudence therefore affect the quality of the outcomes. Another problem is the fact that arbitrators may not be suitable for the purpose they serve. Most of them are white males that went to "Ivy league" universities and are incapable of thoroughly comprehending aspects to local policy and policy space and the need for social justice and redress in domestic countries.

\section{Weakness: no appellate mechanism}

Another inherent weakness of the investor-state dispute settlement system relates to the absence of an appellate mechanism to review decisions of arbitral bodies that might have erred in their awards. An appellate mechanism, it is argued, can ensure consistency in arbitral decisions. ${ }^{58}$ This has led one scholar to state rather prophetically that "the business of developing the law of foreign investment is too important an area to be left to some ad hoc tribunals established under the ICSID or UNCITRAL. Hence, the onus should primarily be on countries. ${ }^{59}$

\section{Potential responses to the challenges facing the investor-state dispute settlement system}

Clearly, therefore, the investor-state dispute settlement system is not without its shortcomings and requires reform. While a single solution that fully satisfies both foreign investors and host nations is highly

54 Johnson "Rethinking bilateral investment treaties in sub-Saharan Africa" 2015 Emory Law Journal 920.

55 Trakman "Investor state arbitration or local courts: Will Australia set a new trend?"2012 Journal of World Trade 108.

56 Mbengue "The Africanization of international investment law: The PanAfrican Investment Code and reform of the international investment regime" 2017 Journal of the World Trade and Investment 442.

57 Johnson 2015 Emory Law Journal 964.

58 Sardinha "The Impetus for the Creation of an Appellate Mechanism" 2017 ICSID Review - Foreign Investment Law Journal 504.

59 Subedi 354. 
unlikely to be achieved, efforts should be made to take into account developing countries' needs. ${ }^{60}$ In this regard, the introduction of an ICSID appeal process similar to the appeal process of the World Trade Organisation (WTO) has been recommended. ${ }^{61}$ Some authors have also suggested that host countries' right to regulate should be featured in the content of their BITs to be able to bring counter-claims in the event of international investment disputes. ${ }^{62}$ Others have proposed adopting an EU-style system to ensure open and transparent international arbitration, prevent treaty shopping and reject trivial matters. ${ }^{63}$ Transpiring from the European Commission's efforts in negotiating the Transatlantic Trade and Investment Partners (TTIP) agreement, there has been talk of the establishment of a permanent investment court as tribunal of first instance, with a proper appeal process and highly qualified judges such as those of the WTO appellate body and the International Court of Justice. ${ }^{64}$

Yet not everyone is equally taken with these proposals. The suggestion of establishing an international investment court has for example been slammed as simply substituting one problem for another. Critics have warned that a permanent investment court would in fact encroach even more on state sovereignty than the current arbitration system, as its judges would not be removable. ${ }^{65}$ They maintain that domestic courts are best positioned to deal with investment disputes in a fair manner by taking into account the domestic circumstances of a particular host country. 66

So, is South Africa's move away from investor-state dispute settlement a breakthrough for establishing a new dispensation of investment relations in the developing world? Or is it a bad omen, foretelling of the steady stifling of foreign direct investment in emerging economies?

60 United Nations Conference on Trade and Development "Reform of investorstate dispute In search of a roadmap" supra.

61 United Nations Conference on Trade and Development "Reform of investorstate dispute In search of a roadmap" supra.

62 Sardinha "The Impetus for the Creation of an Appellate Mechanism" 2017 ICSID Review - Foreign Investment Law Journal 505.

63 Sardinha "The Impetus for the Creation of an Appellate Mechanism" 2017 ICSID Review - Foreign Investment Law Journal 505.

64 Sardinha "The Impetus for the Creation of an Appellate Mechanism" 2017 ICSID Review - Foreign Investment Law Journal 505.

65 Brower \& Schill 2009Chicago Journal of International Law 495.

66 Sornarajah An International Investment Court: panacea or purgatory? Available at https://academiccommons.columbia.edu/doi/10.7916/D8RN3 89W (accessed 2018-02-03). 


\section{Parting with investor-state dispute settlement: a trend in the developing world?}

\section{Comparison of investor-state dispute settlement under South Africa's previous BIT system and dispute resolution under the new Protection of Investment Act}

Investor-state dispute settlement is the legal mechanism that allows multinational corporations a forum, other than the court of the country in which the dispute arose ("host country"), to arbitrate a controversy between a corporation and the host country. ${ }^{67}$ The types of disputes brought through the investor-state dispute mechanisms are alleged harms to the foreign corporation caused by the host country. These claims arise from the substantive provisions of the BITs or trade agreements. By implementing investor-state dispute, host state hope to provide foreign investors with a neutral forum to address claims of expropriation by the host country, to prevent discrimination of foreign corporations by offering them the same rights as local corporations or third-country corporations, and to provide fair and equitable treatment to foreign investors. The problem is that the foreign investors have the exclusive right to file claims through investors-state dispute mechanism. ${ }^{68}$

All South Africa's previous BITs contained a dispute resolution clause that permitted referral to investor-state dispute settlement by the foreign investor. ${ }^{69}$ The dispute settlement mechanism meant that foreign investors had a right to take the South African government to international arbitration for alleged breach of BIT clauses, without requiring the host state's permission. ${ }^{70}$ In so doing, South Africa conformed to the general practice, acknowledging that foreign investors often - and, in many instances, justifiably so - do not have confidence in the impartiality of the host state's judiciary. ${ }^{71}$ Instead, they prefer to have disputes resolved before a neutral tribunal to secure impartial justice. ${ }^{72}$ The dispute resolution clause in the now terminated United Kingdom-South Africa BIT serves as a typical example of the country's investment arbitration dispensation prior to the Protection of Investment Act. The clause read as follows:

“(I) Disputes between a national or company of one Contracting Party and the other Contracting Party concerning an obligation of the latter under this

Agreement in relation to an investment of the former which have not been

67 Schreuer, Investment Disputes 2010 Max Planck Encyclopedia of Public International Law 22.

68 Osmanski "Investor-State Dispute Settlement: Is there a better alternative?" 2018 Brooklyn Journal of International Law 639.

69 Schlemmer 2016 ICSID Review - Foreign Investment Law Journal 182

70 Schlemmer 2016 ICSID Review-Foreign investment Law Journal 182.

71 Sornarajah 216.

72 Sornarajah 216. 
amicably settled shall, after a period of three months from written notification of a claim, be submitted to international arbitration if the national or company concerned so wishes."73

While some of the South African BITs contained slightly different clauses that excluded international arbitration where a foreign investor had specifically chosen to approach the local courts, ${ }^{74}$ none contained a clause requiring that foreign investors first exhaust local remedies, as exhaustion of local remedies posed the risk of creating delays and uncertainty in the process of adjudication.

In contrast, the Protection of Investment Act, specifically provides for dispute resolution through the country's domestic courts, in the following terms:

"13(1) An investor that has a dispute in respect of action taken by the government, which action affected an investment of such foreign investor, may within six months of becoming aware of the dispute request the Department to facilitate the resolution of such dispute by appointing a mediator."

"(4) Subject to applicable legislation, an investor, upon becoming aware of a dispute as referred to in subsection (1), is not precluded from approaching any competent court, independent tribunal or statutory body within the Republic for the resolution of a dispute relating to an investment. (5) The government may consent to international arbitration in respect of investments covered by this Act, subject to the exhaustion of domestic remedies. The consideration of a request for international arbitration will be subject to the administrative processes set out in section 6. Such arbitration will be conducted between the Republic and the home state of the applicable investor., 75

In a rather drastic step, any reference to international investor-state arbitration, and thus the "depoliticisation" of investment disputes, has therefore been removed. Foreign investors will first be subjected to an asyet untested mediation process led by the Department of Trade and Industry. ${ }^{76}$ This does not bode well for attracting foreign investors. ${ }^{77}$ Section 13(5) contains the only exception, permitting arbitration to be conducted between South Africa and the investor's home state, though still only once domestic remedies have been exhausted. This is little consolation, however, as the exhaustion of domestic remedies takes time, and the foreign investor cannot be certain that his home state would feel it necessary to intervene once all local remedies have been put to the test. ${ }^{78}$ In addition, the legislature's choice of the words "may

73 S13 of the Protection of Investment Act 22 of 2015.

74 Schlemmer 2016 ICSID Review - Foreign Investment Law Journal 182.

75 S13 of the Protection of Investment Act 22 of 2015.

76 Regulation 7(2) in terms of GN 958 in GG 40526 of 30-12-2016. The investor and the department can jointly appoint a mediator from the list maintained by the department.

77 Notably, the European Union's Regional Chamber of Commerce and Industry.

78 Schlemmer 2016 ICSID Review - Foreign Investment Law Journal 182 
consent to international arbitration" in this subsection allows government wide discretion to refuse to consent to such arbitration for fear that the international tribunal might scrutinise its domestic policies.

It is therefore safe to conclude that by removing the investor-state arbitration method of resolving investment disputes, the South African government has severely eroded the protection to which the country's foreign investors have become accustomed. ${ }^{79}$

\section{Spotting a trend amongst developing countries}

While South Africa's decision to suspend its BITs and do away with investor-state dispute settlement has caused a stir, ${ }^{80}$ the country is by no means the only one choosing to step back from international investment arbitration. Nations such as Bolivia, Ecuador and Venezuela have also terminated several international investment agreements and withdrawn from the ICSID, ${ }^{81}$ India has frozen all investment negotiations, ${ }^{82}$ and the Union of South American Nations (UNASUR) has created an alternative investment arbitration forum. Also in terms of Brazil's new partnership agreements, state-to-state resolution is the last resort for dispute settlement, with no reference being made to investor-state dispute settlement. ${ }^{83}$ China, in turn, has introduced the exhaustion of local remedies as a prerequisite for investor-state dispute settlement to occur. ${ }^{84}$ Although a developed nation, Australia too has indicated that it will no longer agree to investor-state dispute settlement in their international investment agreements, and that disputes would be resolved before the national courts. Assessing investor-state dispute settlement on a case-by-case basis, the country recently concluded an investment treaty with the Pacific Islands that excludes international dispute settlement, instead providing for dispute resolution in national courts or through a mechanism mutually agreed by the parties. ${ }^{85}$ Central to developing nations' increasing move to terminate and or make fundamental changes to their international investment frameworks is the fact that investor-state dispute settlement exposes developing countries to heavy penalties. ${ }^{86}$ Moreover, there is growing evidence that countries are eager to balance investment protection with the host state's right to regulate for public benefit. ${ }^{87}$ A new generation of BITs are emerging that

79 Qumba 2018 South African Journal of International Affairs 354.

80 Markus Schrader, head of economic cooperation and development at the Embassy of Switzerland, is reported to have said: "The South African government was not in a position to take such measures, considering South Africa's relatively low ranking in reports like Doing Business."

81 Osmanski 2018 Brooklyn Journal of International Law 639.

82 Osmanski 2018 Brooklyn Journal of International Law 639.

83 Art 24 cooperation and facilitation investment Agreement of the Federative Republic of Brazil.

84 Art 9(2)(b) of the Chinese model BIT version III.

85 UNCTAD World Investment Forum, Traidcraft Exchange "International investment agreements under scrutiny" available at https://www.tni.org/ files/downloads/iias_report-feb_2015.pdf

86 Occidental Petroleum v Ecuador ICSID Case No ARB06/11 of 5 Oct 2012. 
attempt to strike a balance between these competing goals. ${ }^{88}$ This is done in a bid to limit the power of arbitral tribunals and ensure that host states' regulatory power remains unimpaired. ${ }^{89}$

At a regional level, this has also seen a determined move on the part of the Southern African Development Community (SADC), which has removed the investor-state arbitration provided for in its 2006 Protocol on Finance and Investment (FIP), with article 25 of the 2016 edition now providing for access to domestic courts and tribunals for foreign investors. In effect, this means that the 2016 SADC FIP deals with statestate arbitration only. This follows South Africa's proposal during the consultative process that article 28 of the 2006 SADC FIP be removed due to concerns about the way in which investor-state disputes were being dealt with by international tribunals. ${ }^{90}$ These concerns included a "perceived lack of transparency and legitimacy of the international arbitration process, conflicting arbitral jurisprudence, the independence of arbitrators and the prohibitive legal costs associated with international commercial arbitration and excessive damages".91 Although none of the SADC member states showed any intention to remove investor-state arbitration at the time, ${ }^{92}$ the 2016 SADC FIP shows clear signs of a growing dissatisfaction with this dispute resolution mechanism. Therefore, the 2016 SADC FIP surprisingly maintains the defunct SADC tribunal, despite that body's questionable legitimacy. ${ }^{93}$ Following the matter of Mike Campbell $v$ Republic of Zimbabwe, ${ }^{94}$ the SADC tribunal suffered a blow to its integrity, and in effect became toothless. In that case, the Zimbabwean government failed to abide by the tribunal's decision after the country was found to have been in breach of the provisions of the SADC treaty. In particular, the Zimbabwean government was found to have committed unlawful expropriation for refusing to pay compensation after it had taken possession of private property. In response, the Zimbabwean government questioned the legitimacy of the tribunal and lobbied for political support, which eventually saw the tribunal being suspended. One may therefore question how a tribunal that has fallen into disrepute would protect foreign investors, having previously failed to enforce its awards.

87 Churchill Mining PLC and Planet Mining Pty Ltd $v$ Republic of Indonesia ICSID Case No. ARB/12/40.

88 Churchill Mining PLC and Planet Mining Pty Ltd $v$ Republic of Indonesia supra.

89 Churchill Mining PLC and Planet Mining Pty Ltd $v$ Republic of Indonesia supra.

90 Kondo" A Comparison with Analysis of the SADC FIP before and after its Amendment" 2017 Potchefstroom Electronic Law Journal 34.

91 Trakman "Investor state arbitration or local courts: Will Australia set a new trend?"2012 Journal of World Trade 108.

92 Kondo 2017 Potchefstroom Electronic Law Journal 34.

93 Art 26SADC FIP

94 Mike Campbell (Pvt) Ltd \& Others v Republic of Zimbabwe (2/2007) [2008] SADCT 2 
Displaying an equally negative attitude towards ISDS in the SADC region is the SADC model BIT, which recommends that member states in the region reject this dispute settlement mechanism. ${ }^{95}$ Similar to the 2016 SADC FIP, the model BIT seems to favour a state-state dispute settlement approach that permits state parties to initiate arbitration on behalf of foreign investors for an alleged violation of a treaty provision, although only subject to the exhaustion of local remedies or if a contracting state can demonstrate that there are no local remedies available. ${ }^{96}$ This approach again throws up the challenges of political interference and questions about the independence of domestic courts, and may see foreign investors rather opting for other investment destinations that would still allow them to turn to the ICSID or another international arbitral tribunal in the event of a dispute. However, it remains to be seen whether African countries in the SADC region will eventually adopt the recommendations of the model BIT. The only country that has indicated its intention to do so is South Africa. ${ }^{97}$

Developing countries and African countries in particular, seem eager to prove that their judiciaries are sufficiently independent and robust and their jurisdictions adequately equipped to deal with international investment matters. ${ }^{98}$ Another interesting development in the African region is the new Pan African Investment Code (PAIC). In 2016, during the last consultation of African Union (AU) ministers in charge of regional integration, the AU developed the draft PAIC. ${ }^{99}$ The objective of the code is to promote, facilitate and protect investments that foster sustainable development in member states, particularly in the member state where the investment is located. ${ }^{100}$ In terms of the code, investment disputes should be resolved within six months through consultations and negotiations. ${ }^{101}$

The code provided for the option of excluding a provision on investorstate arbitration in an international forum. ${ }^{102}$ Instead, the code provides for an arbitration system that may be conducted at any established public or private African alternative dispute resolution centre. ${ }^{103}$ Although the code is but a guide and non-binding, it does serve as a prime example of the move away from international investor-state arbitration forums towards investment resolution in African-based centres. With regard to arbitration between home and host states, article

\footnotetext{
95 Art 29 SADC model BIT.

96 Art 29 SADC model BIT.

97 TRALAC available at https://www.tralac.org/publications/article/6771-thesadc-model-bilateral-investment-treaty-template-towards-a-new-standardof-investor-protection-in-southern-africa.html (accessed 8 August 2018).

98 Kidane Alternatives to investor-state dispute settlement: an African perspective (2018).

99 The draft Pan African Investment Code was amended in Nairobi, Kenya, in November 2016.

100 Art 1 of the Pan African Investment Code.

101 Art 42(1)(b) Pan African Investment Code.

102 Art 42(1)(d) Pan African Investment Code.

103 Art 42(1)(d)Pan African Investment Code.
} 
41(1) of the PAIC requires states to consent to arbitration, which must be conducted in an established public or alternative African dispute resolution centre. ${ }^{104}$ The requirement to agree to arbitration, however, assumes that both the home and host state are willing to arbitrate against each other. ${ }^{105}$ Currently, state-state arbitration is very rare in international investment jurisprudence. States may therefore opt against arbitration in an effort to protect economic and political relations, which would leave the foreign investor's cause of complaint without appropriate redress. ${ }^{106}$ Yet the proposal of creating venues for African arbitration is a promising innovation that may go a long way towards growing African capacity and challenging the general perception that African judiciaries are ineffective.

The inclusion of an ISDS provision in the PAIC was hotly debated among African member states, and the investor-state dispute resolution clause contained in the code could therefore be considered a compromise. ${ }^{107}$ With some SADC states fiercely opposing the inclusion of an ISDS provision, and others seeking its inclusion, article 42(1) was drafted to accommodate these divergent approaches. This provision gives each member state control over the investor-state arbitration process, and safeguards domestic policies. It requires member states to agree to utilising an investor-state dispute settlement mechanism that aligns with their domestic policy directives, thereby countering foreign investors' unilateral power to refer investment disputes to ICSID arbitration without first seeking host states' consent.

Surprisingly, article 42(1)(a) of the PAIC then affords member states and investors leeway to resolve investment disputes under those agreements that govern their relations, which reveals that many African member states do still see a need for ISDS to attract foreign investment inflows, and are not necessarily set on doing away with ICSID arbitration altogether. ${ }^{108}$ From this, it would appear that a number of African nations realise that they are unlikely to attract foreign investment if they do not afford foreign investors the right to challenge them before an independent investment tribunal of sorts. ${ }^{109}$ In this regard, the PAIC can therefore be said to grant member states a middle-ground solution to either make use of ISDS or reject it, depending on each member state's choice.

In article 42(1)(b), the code encourages the resolution of disputes through consultations and negotiations. ${ }^{110}$ Admittedly, resolving disputes through consultations and negotiations would serve to maintain

104 Art 41(1)(d)Pan African Investment Code.

105 Art 41(1)(d) Pan African Investment Code.

106 Schlemmer 2016 ICSID Review - Foreign Investment Law Journal 182.

107 Mbengue 2017 Journal of the World Trade and Investment 442.

108 Mbengeu 2017 Journal of the World Trade and Investment 443.

109 Johnson 2015 Emory Law Journal 965.

110 Art 42(1)(b) Pan African Investment Code. 
business relations between foreign investors and host governments. ${ }^{111}$ However, in the event of small to medium-sized foreign investors, the drawbacks associated with such consultations and negotiations may be considerable. ${ }^{112}$ In this respect, therefore, it is argued that the PAIC offers less protection to this specific category of foreign investor, who might lack sufficient negotiating power compared to the host government.

Generally, the choice of law by both parties to a treaty is fundamental, as it may determine the outcome of any potential investment dispute. It is worth emphasising that both parties normally agree on the applicable law, which is then binding on arbitrators, who may only exercise their discretion in the absence of an express choice of law in a treaty. ${ }^{113}$ Under article 42(1)(c) of the PAIC, however, disputes may be resolved through arbitration, subject to the applicable laws of the host state, ${ }^{114}$ - laws which foreign investors may not be acquainted with. Moreover, article 42(1)(c) introduces the exhaustion of local remedies before resort is made to arbitration. ${ }^{115}$ This may be equally worrisome to foreign investors, as the time lost exhausting local remedies could be detrimental to their business interests.

Further compromising the protection of foreign investors in this provision of the PAIC is its implied restriction on investors' access to ISDS. While ISDS may be considered, this is made subject to the national laws of the host state and or mutual agreement between the host state and foreign investor. In effect, therefore, if an African country's national laws do not permit ISDS, as is the case in South Africa's Protection of Investment Act, foreign investors cannot refer disputes for arbitration by the ICSID or any other international body. ${ }^{116}$ Moreover, where the host state's laws do allow for ISDS, both disputing parties first have to agree to follow this route. ${ }^{117}$

Should consultations fail, disputes may be referred for arbitration, subject to the applicable laws of the host state and or the mutual agreement of the disputing parties, as well as the exhaustion of local remedies. This code too does away with international arbitration, although provision is made for arbitration to be conducted at any established African public or private alternative dispute resolution centre or the Permanent Court of Arbitration Centres in Africa. ${ }^{118}$

111 Salacuse "Is there a better way? Alternative methods of treaty-based, investor-state dispute resolution" 2007 Fordham International Law Journal 141.

112 Schill 2016 European Yearbook of International Economic Law 112.

113 Banifatemim 'The law applicable in investment treaty arbitration' in Yannaca-Small (ed), Arbitration under International Investment Agreements: A Guide to the Key Issues (2010) 191.

114 Art 42(1)(c)Pan African Investment Code.

115 Art 42(1)(c) Pan African Investment Code.

116 S 13 of the Protection of Investment Act 22 of 2015.

117 Art 42(1)(c) Pan African Investment Code.

118 Art 42(1)(c) Pan African Investment Code. 
Therefore, the contemporary trends in treaty practice show that host countries, particularly those in the developing world, are keen to assume a level of regulatory control instead of simply leaving all dispute resolution and regulation to international arbitrators. South Africa is thus not alone in questioning investor-state dispute settlement. Add to that the poor African representation in terms of the number of arbitrators at the ICSID, ${ }^{119}$ and the country's move away from the investor-state dispute settlement system does not come as much of a surprise. Of greater concern, though, is the fact that the South African judiciary is not generally known for its expertise in the field of international investment law, while the as-yet untested mediation and arbitration processes of the Department of Trade and Industry will not do much to allay foreign investors' fears.

\section{The way forward}

The legal framework for foreign investors is crucial in creating a climate conducive to investment. Moreover, a key element of this framework is an impartial and effective dispute settlement mechanism between host states and foreign investors. For decades, investor-state dispute settlement at the ICSID served this purpose, but the system has recently encountered opposition from host nations wanting to play a more active role.

As seen from the discussion above, the dissatisfaction with investorstate dispute settlement stems from the fact that it affords the foreign investor a unilateral right, whilst the government of the host nation does not enjoy that same entitlement. Despite improvements in recent times, the system remains unbalanced, with no apparent move to enable host states to initiate proceedings against foreign investors. The only developments in recent treaty drafting is the provision for counter claims rather than the states making direct claims against foreign investors. For example, article 43 of the Pan African Investment Code allows a host government to file a counterclaim during ISDS. To this end, the article provides that where an investor is alleged to have failed to comply with the provisions of the PAIC, the competent body dealing with such a dispute shall consider whether the breach is materially relevant to the issues before it, and if so, what offsetting effects this may have on the merits of the investor's claim or on any potential damages awarded. ${ }^{120}$ It should be noted, however, that the ICSID Convention already permits host governments to file counterclaims against foreign investors upon the fulfilment of certain conditions. ${ }^{121}$ The provision for counterclaims in recent treaty drafting, in turn, allows host governments to invoke relevant treaties protecting human rights, environmental and labour

119 Mbengeu 2017 Journal of the World Trade and Investment 443.

120 Art 43(1) Pan African Investment Code.

121 Art 46; ICSID arbitration rule 40I CSID Convention. 
standards. ${ }^{122}$ Yet, even though these treaties protect important cornerstones of democracy, such as human rights and environmental sustainability, this does raise the question whether African countries would not perhaps invoke counterclaim defences simply to undermine legitimate claims by foreign investors. ${ }^{123}$

Staunch critics of investor-state dispute settlement have concluded that the system is not worth preserving, as its existence comes at the expense of host states' regulatory mechanisms and restrict their ability to make policies suited to the nation. These arguments have seen a trend of stepping back from investor-state dispute settlement in the developing world, with the South African government now also having distanced itself from the ICSID and terminated its BITs with foreign investor countries. With a new generation of BITs emerging, many more in the developing world may soon follow suit. However, is a sudden outright rejection of investor-state dispute settlement, without first establishing some sort of alternative capacity, wise? Will foreign investors have the stomach to stick it out and see whether future investment disputes can indeed be satisfactorily resolved through domestic means? In resourceconstrained times, it might be more prudent to safeguard valuable inflows of investment and resist the temptation of scrapping investorstate dispute settlement in its entirety, at least until workable alternatives have been identified, tried and tested.

One such alternative could be the initiation of strong regional efforts amongst developing countries, coming together as a bloc towards creating a sensible, custom-made system of international investment arbitration - with African countries creating an African solution for a unified system that could take the interests of foreign investors as well as the continent's needs into account. Such an approach could for example incorporate the appointment of regional arbitrators, who are more likely to understand the unique circumstances of emerging economies. What would make this more appealing than the suggested way forward in South Africa's new Protection of Investment Act is that disputes would be settled based on the common understanding of a group of developing countries instead of through a unilateral decision by a single host State.

Until such an ideal can be achieved, the best interim measure may be for developing countries to insist on and monitor improvements in the investor-state dispute settlement process to make it more transparent. This could include bringing pressure to bear on international lawmakers to introduce local litigation as a precondition for investor-state dispute settlement. It could entail pushing for the introduction of an appeal process to seek redress, not only on procedural aspects, but also on the merits of a case to call arbitrators to account. It could involve campaigning to have stronger African and developing-country representation in the ICSID and any future appellate body to ensure

122 Art 43(1)Pan African Investment Code.

123 Trakman 2012 Journal of World Trade 604. 
broader representation and inspire confidence in the system. Nevertheless, for this to occur, developing nations must - for now remain part of the system.

Judging by host nations' objections against investor-state dispute settlement, South Africa's outright rejection of the system in exchange for investment arbitration through domestic means is not that surprising. To some, it may even seem like a breakthrough, finally affording the country more control over how foreign investments are regulated and managed. It is only hoped that this move does not go down in history as a bad omen that foretold of a final breakdown in investor confidence and the drying up of capital inflows into a country and continent that desperately needed it. 